\title{
Understanding the Challenges Facing Occupational Health Services in the Swedish Public Sector ${ }^{\prime}$
}

I Lisa Schmidt ${ }^{2}$

MSc, PhD Student, IVL Swedish Environmental Research Institute, Sweden

I John Sjöström

PhD, IVL Swedish Environmental Research Institute, Sweden

I Ann-Beth Antonsson

Adjunct professor, IVL Swedish Environmental Research Institute, Sweden

\begin{abstract}
According to Swedish Work Environmental Act, all organizations are required to implement Occupational Health and Safety Management (OHSM). In support of this and when competence within the employer's own organization is insufficient, regulations state that the employers are required to employ external resources such as an Occupational Health Service (OHS) provider.The aim of this study was to explore how public sector organizations utilized services and support from their OHS provider in preventive OHSM. Eleven public sector organizations were studied, 100 of respondents (politicians, managers, HR, safety representatives, and OHS professionals) interviewed, and the data collected qualitatively and thematically analyzed. The results showed that the $\mathrm{OHS}$ providers do not support the public-sector organizations with preventive OHSM according to the intentions of the legislation. A significant conclusion is that the HR department has an important role in the collaboration and for the utilization of preventive services in OHSM.
\end{abstract}

\section{KEYWORDS}

HR department / occupational health services / occupational health and safety management / public sector / Sweden / work environment

\section{Introduction}

he overall aim of Occupational Health and Safety Management (OHSM) is to establish an effective prevention of work-related ill-health and to achieve beneficial working conditions. The question is whether or not Occupational Health Service (OHS) providers contribute to these goals in the public sector. This article will explore processes and contextual conditions for the use of OHS providers in the Swedish public sector.

\footnotetext{
${ }^{1}$ You can find this text and its DOI at https://tidsskrift.dk/njwls/index.

${ }^{2}$ Corresponding author: Lisa Schmidt, IVL Swedish Environmental Research Institute, Box 21060, 100

31 Stockholm, Sweden. E-mail: lisa.schmidt@ivl.se.
} 
According to Swedish legislation and regulation, the employer shall cooperate with employees in their preventive OHSM in order to create healthy and safe workplaces (Swedish Work Environment Authority, 2014a). OHSM in the strategy's mandatory form, EU's framework Directive (89/391(EEC; from 1989), specifies how employers should manage the work environment and the primary objective is for employers to protect employees from risks at work (Frick, 2014). To work preventive and systematically with the work environment is a continuous process with recurring activities, and in order to achieve this, it needs to be an everyday aspect of work. The Plan-Do-CheckAct model is basic in preventive OHSM, and to achieve continuous improvement, it is important to identify and address all types of risks at work and to have an effective monitoring process to reduce accidents, injuries, and ill-health. In support of this process when competence within the employer's own organization is insufficient, legislation states that the employer shall employ external resources such as an OHS provider (Swedish Work Environment Authority, 2001). The Work Environment Act defines the role of an OHS provider as working specifically to prevent and eliminate health hazards in the workplace and providing the skills necessary to identify and explain connections between the working environment, organization, productivity, and health and safety (Swedish Work Environment Authority, 2014b). An OHS provider is not part of the public health, but operates as an independent company in an open market or is incorporated into the organization (Gunnarsson et al., 2011). Compared to the Nordic countries, the Swedish OHS providers are among the least regulated with no monitoring or evaluation of the system of OHS providers (Hämäläinen et al., 2001). In the discussion of the role and tasks of the OHS provider, it is important to consider the differences of OHS systems between countries (Westerholm et al., 2000). The role given to OHS provider by law and regulation differs between countries, which makes comparison difficult. It would be very complex and give little insight in how to make best use of OHS within each given context.

Similar requirements for the provision of the preventive services are defined in many national laws (Fedotov, 2005). The Nordic countries have considerable different solutions; in Finland, it has been obligatory for employers to arrange preventive OHS since 1979 (Kankaanpää, 2008, 2013). In Norway, the enforcement of the Law on the Working Environment became stricter and an accreditation system for OHS providers was introduced in 2010. Now, an OHS provider has to be authorized by the Norwegian Labour Inspection Authority (Vinberg et al., 2015, 2017). The accreditation system has improved the quality of the OHS providers' in Norway, for example, increased professional competence and multidisciplinary working (Lie \& Bjørnstad, 2015). A new OHS system has also been introduced in Denmark in 2005. Thereafter, the Danish Working Environment Authority screen enterprises at a kind of informal inspection and then defining which problems require advice from an OHS provider (Danish Government, 2011; Arbejdstilsynet, 2013).

Deficiencies in OHSM in municipalities and county councils in Sweden have been identified (Frick, 2013b; Dellve et al., 2004). In the public sector, most work is service work, largely done by women (Kamp et al., 2013a; Swedish Agency for Public Management, 2015) and bearing in mind the high rates of absenteeism due to illness and longterm sick leave in the public sector (Vingård et al., 2005; Lund et al., 2008; Sverke et al., 2016), it is of interest to study how OHS providers are utilized in the public sector. This is particularly of importance since it has been shown that the prevalence of long-term

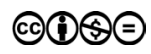


work ability is higher in municipalities where there is a well-structured OHSM (Dellve et al., 2008). According to the trade association of Swedish OHS providers (Sveriges Företagshälsor, 2016), most employees in the public sector have access to an OHS provider. However, access says nothing about how, or indeed if, these OHS services are utilized. Therefore, this study explores the support provided by OHS providers in terms of preventive OHSM to clients in the public sector.

In Sweden, the traditional model of the work environment management is based on Nordic traditions, which include strong local trade unions and safety representatives (Frick, 2011; Sjöström \& Frick, 2017). This is reflected in the assumption that OHSM should generally be managed with the participation and cooperation of employees and their safety representatives (Frick, 2013a). The importance of safety representatives for preventive actions at the workplace has been highlighted (Dellve et al., 2004; Walters \& Nichols, 2007; Frick, 2014; Olle'-Espluga et al., 2015). At a workplace where 50 workers or more are regularly employed, there must be a safety committee consisting of representatives of both employers and employees (Swedish Work Environment Authority, 2014c). The utilization of an external resource such as an OHS provider is not mandatory, but shall be decided within the OHSM process. Hence, employees and/or safety representatives shall be involved in decisions on utilization of services.

In addition to legislation, there are guidelines and recommendations defining how the regulations should be implemented (Swedish Work Environment Authority, 2001). These guidelines are not binding but explain how the regulation should be interpreted. It states that 'it is essential that employees and safety representatives should be given the opportunity of participating in the procurement of OHS providers and in decisionmaking on the structuring and realization of the contract' and that 'services and support from the OHS provider shall be available for both employer and employees'.

\section{Changing context}

In order to understand how support from the OHS provider is provided and utilized, we need to explain the complex and changing context in the Swedish public sector during last decades. Municipalities and county councils are among the largest employers in Sweden, employing over a million people out of a total of population of just fewer than 10 million with about $80 \%$ of these being women (Swedish Agency for Public Management, 2015). Divided into 290 municipalities and 20 county councils, including four regions, there is a great deal of variation in demographics, geographic size, and number of employees. Consequently - as politically self-governing local authorities - there is enormous scope for organizing and adapting operations to local and regional conditions.

Sweden's political system is based on the principle that decisions taken by elected politicians shall be put into practice by professional officials on local government committees or in public administration (Frick, 2013a). Prerequisites for and overall limits on the practice, form, organization, and management of OHS provision is set by politicians, as well as the overall objectives and economic conditions such as budgets for utilizing services. The political governance enables the public sector organizations to find a model perceived as best for collaboration with their OHS provider; motivated by knowledge, tradition, market, conditions, and political ideology. Ultimately, politicians also bear employer responsibility for public-sector organizations. 
Over recent decades, working conditions in the public sector have changed significantly under political pressures to improve efficiency. Reforms and changes have to a large extent been in accordance with the principles of New Public Management (NPM) (Kamp et al., 2013a). With many management practices drawn from the private sector, outsourcing and privatization were common. Reforms consisted to a large extent of changes in management models, for example, managing for results, the decentralization of activities, the introduction of performance management and financial control systems; in other words, private sector practices transplanted to the public sector. These public-sector organizations came to be regarded as businesses, buying and selling their services on a fictional marketplace. Contracting between separated purchaser and provider was introduced (Hall, 2013; Paulsson, 2012), and today, the public sector is a large purchaser of utilities, professional services, and temporary labour, etc. This NPM transformation also has affected working life, with negative consequences for working conditions, as increasing demands and decreasing resources (Hasselbladh et al., 2008; Selberg, 2013) have an impact on occupational health and safety (Diefenbach, 2009; Ibsen et al., 2011; Målqvist et al., 2011; Kamp et al., 2013b).

In the Nordic countries, worker representation has been seen as a key support for effective preventive OHSM. Over recent decades, trade union membership has decreased. In Sweden, this decline has also affected workplaces and worker safety representation (Sjöström \& Frick, 2017). This is problematic, as legislation requires employers to consult health and safety representatives with regard to OHSM. This development, along with the change of management model and new business practices in the Swedish public sector, has occurred in parallel to the transformation of the status of Human Resource (HR) professionals. Historically, the HR function within the public sector has been regarded as peripheral and relatively powerless (Truss, 2008). Now, the imposition of NPM principles has led to new ways of managing in the public sector and HR has become more strategically involved in the organization (Brown, 2004). HR professionals have re-emerged in a new role, functioning as consultants and partners in the management of the organization, more strategically oriented with tasks including organizational development and employer branding (Boglind et al., 2011).

The development of the public sector has also affected the business of OHS providers since the state funding which partly financed the OHS providers was abolished in 1993. Today, there is no subsidy for employing an OHS provider and the business have become market-oriented, streamlined, and merged into larger organizations. Today, there are about 150 OHS providers in Sweden, approximately $80 \%$ of them are external OHS providers. The remaining $20 \%$ are in-house OHS units, half of which operate in the public sector and the other half within large corporations (Sveriges Företagshälsor, 2016). Clearly, many public-sector organizations may find it necessary to employ the services of an external OHS provider.

Since municipalities and county councils are governed by the Swedish Public Procurement Act (SFS, 2007:1091), specific procedures regulate the purchase of public supply contracts and public service contracts. The procurement process and the question of how to utilize OHS providers should, according to legislation and recommendations regarding its implementation, be an issue for the employer and the safety committee including safety representatives, as a form of worker representation in health and safety and as a process to identify needs in OHSM (Swedish Work Environment Authority, 2014c). 
An OHS provider has no explicit social responsibility to deliver a given service; there are no regulations regarding which services they are required to provide. Therefore, it is important to distinguish between the services described by the regulations and the services OHS providers usually deliver. There are no uniform, comparable statistics available of different types or volumes of services from OHS providers.

OHS providers are often referred to in the course of public debate, described by the social partners as an important resource for occupational health and safety and a support for preventive OSHM. Although concerns are voiced about what OHS providers should or should not do - treatment or prevention - there is relatively little evidence as to what is actually being done, especially regarding preventive OHSM. Concerns about impact and effectiveness have been raised during recent decades. In 2001, an official report suggested several improvements to OHS organizations (Swedish Agency for Public Management, 2001) and further public investigations and research (Westerholm \& Bostedt, 2004; SOU, 2004:113; SOU, 2007:91; SOU, 2011:79) have continued to the discussion on the role, impact, and effectiveness of OHS providers. Even so, according to current statistics from members of the Swedish association of OHS providers as well as research, the most common service provided is health examination, followed by services related to individual lifestyle issues and support for rehabilitation (Sveriges Företagshälsor, 2016).

In summation, over recent decades, the public sector has changed and high levels of sickness-related absenteeism and deficiencies in OHSM have been identified (Frick, 2013a). Here, OHS providers could be a support, but there is a research gap regarding how collaboration between OHS providers and municipalities and county councils works and how their services are utilized. Therefore, the aim of this study was to explore how public-sector organizations utilize services and receive support in preventive OHSM from their OHS provider. The following questions are of interest: How is OHSM organized and implemented? How are OHS providers supporting municipalities and county councils in preventive OHSM? What support and services are utilized? How are the relations and collaborations between public sector employers and OHS providers organized? What are their respective goals and how do they perceive the collaboration?

\section{Methods and Materials}

\section{Study design}

This was a qualitative study based on data collected through individual and focus-group interviews in which the utilization of OHS providers was investigated based on the views of professionals working in municipalities and county councils and at the OHS providers. The project was conducted in consultation with a reference group consisting of representatives for the social partners, a researcher, a representative of the trade association of OHS providers, and a representative of the Swedish Work Environment Authority. In order to find public-sector organizations, an advertisement was published on the webpage of the industry association of OHS providers to inform interested public-sector organizations or in-house OHS units about the project and to encourage them to make contact if they were interested in participating. A few organizations were reached in this way, but in order to find a multitude of cases, a total of 25 public-sector organizations were identified 
through the agency and advice of the reference group. Initially, telephone interviews were conducted with OHS managers of in-house OHS units and with HR managers in public-sector organizations with external OHS providers. This first contact was in order to present the study and discuss how the collaboration between the OHS provider and the organization worked. It was also an opportunity to explain the prerequisites for taking part in the study. The summarized results of these interviews were discussed with the reference group and, in order to achieve variation, cases were selected to reflect the variation in geographical location and size of the public-sector organizations and a combination of in-house units and external OHS providers. A total of 11 public-sector organizations were selected: seven municipalities and four county councils/regions (Table 1).

Table I Participating organizations

\begin{tabular}{cccc}
\hline Municipalities & $\begin{array}{c}\text { County councils/ } \\
\text { Region }\end{array}$ & $\begin{array}{c}\text { External OHS } \\
\text { provider }\end{array}$ & In-house OHS unit \\
\hline$\times$ & & $\times$ & \\
$\times$ & & $\times$ & \\
$\times$ & & $\times$ & \\
$\times$ & & $\times$ & $\times$ \\
$\times$ & & & $\times$ \\
$\times$ & $\times$ & & $\times$ \\
$\times$ & $\times$ & & $\times$ \\
& $\times$ & & $\times$ \\
& $\times$ & & $\times$ \\
$(x)^{*}$ & $\times$ & & \\
$(x)^{*}$ & & & \\
\hline
\end{tabular}

*Customers to the in-house OHS unit were both municipalities and a county.

The municipalities included both small and large, located geographically from north to south in Sweden, and represented both urban and rural areas. Five of these had procured an external OHS provider and remaining two had in-house OHS units. The four county councils/regions varied slightly in size but all had their own in-house OHS units. Two of these in-house OHS units were also suppliers to a varying number of municipalities not included in this study. Eleven organizations were selected, five with an external OHS provider and six with their own in-house OHS unit, and contacted with all agreeing to participate in the study. An appropriate time for a visit and interviews was established.

\section{Data collection}

Since the study wanted to identify interactions and understand and acquire knowledge of the relationship between OHS providers and clients, interviews were conducted with a qualitative approach with the emphasis on how the respondents expressed and formulated their opinions. A semi-structured interview guide covered a variety of themes, including 
- Current issues regarding health and safety at work in the organization;

- Identification of needs and requirements;

- Employee participation;

- Structure of OHSM, perceptions of strengths, and weaknesses;

- Contracts, agreements, and budgets for OHS provider support;

- Relationships, collaboration with the OHS provider, differences in utilization and use;

- Perceived effects, attitudes, and opinions on the results of the support;

- Significance of the services carried out in the organization by the OHS provider;

- Impact from political governance;

- Future commitment; strategic aspects and contents of OHS services.

Following the case-study recommendation to combine multiple sources (Yin, 1994), the contact person in each case helped to identify the potential respondents, using personal contacts and snowballing techniques. There may be a risk that the study will reflect the contact person's network's picture of the problem but, in order to avoid this, the project more specifically wanted a strategic sample with respondents (managers and health and safety representatives) from different levels of the hierarchy and not belonging to a single department. The inclusion criteria for managers to be selected were to have responsibility for work and safety and significant experience of services and support from the OHS provider, enabling them to have increased awareness, knowledge, and experience of the subject. From OHS providers, depending on availability and relationship to the publicsector organization, both managers and OHS professionals were invited to participate.

The data were gathered by two researchers, conducting 75 interviews with a total of 100 respondents. The interviews were conducted mainly during 2 days at each organization and a convenient location was arranged by the contact person. Face-to-face interviews were carried out with HR managers, health and safety representatives, and first-line managers in order to understand the nature of the collaboration; Interviews were also conducted with representatives of OHS providers, both in-house units and external OHS providers, consisting of managers with responsibility for customer relations and other $\mathrm{OH}$ professionals. Two interviews with health and safety representatives were carried out by telephone (Table 2).

Focus group interviews were conducted on 17 occasions (five consisting of managers, four of health and safety representatives, four of OHS professionals, three of HR staff, and one of politicians). Each group consisted of two to three respondents and two researchers moderating the discussion. The focus group interviews were based on individual perspectives and the researchers encouraged each respondent to participate in the discussion to ensure that opinions on and attitudes toward relevant issues were obtained. All individual interviews and focus groups lasted between 60 and 90 minutes and were recorded. All respondents gave their consent to recording the interview and were guaranteed anonymity in the reporting.

\section{Data analysis}

Analysis of the data began during the study, with the researchers discussing differences and impressions after each interview-session as well as with the reference group on an ongoing basis during the project. All interviews were transcribed verbatim by a professional 
Table 2 Number of respondents

\begin{tabular}{|c|c|c|c|}
\hline & Public-sector organization & OHS provider & $\begin{array}{c}\text { Number of } \\
\text { interviewees }\end{array}$ \\
\hline I & $\begin{array}{c}\text { Municipality } \\
4 \text { managers } \\
2 \text { HR professionals } \\
2 \text { safety representatives }\end{array}$ & $\begin{array}{c}\text { External OHS provider } \\
\text { I OHS manager } \\
2 \mathrm{OHS} \text { professionals }\end{array}$ & II \\
\hline 2 & $\begin{array}{l}\text { Municipality } \\
\text { I manager } \\
\text { | safety representative }\end{array}$ & $\begin{array}{l}\text { In-house OHS unit } \\
\text { | OHS manager } \\
\text { | OHS professional }\end{array}$ & 4 \\
\hline 3 & $\begin{array}{c}\text { Municipality } \\
2 \text { managers } \\
2 \text { safety representatives }\end{array}$ & $\begin{array}{l}\text { In-house OHS unit } \\
\text { I OHS manager } \\
2 \mathrm{OHS} \text { professionals }\end{array}$ & 7 \\
\hline 4 & $\begin{array}{c}\text { County council } \\
2 \text { managers } \\
\text { I HR professional } \\
2 \text { safety representatives }\end{array}$ & $\begin{array}{l}\text { In-house OHS unit } \\
2 \mathrm{OHS} \text { professionals }\end{array}$ & 7 \\
\hline 5 & $\begin{array}{l}\text { County council } \\
3 \text { managers } \\
3 \text { HR professionals } \\
\text { I safety representative }\end{array}$ & $\begin{array}{l}\text { In-house OHS unit } \\
\text { I OHS manager } \\
2 \mathrm{OHS} \text { professionals }\end{array}$ & 10 \\
\hline 6 & $\begin{array}{l}\text { County council } \\
2 \text { HR professionals } \\
\text { | Safety representative }\end{array}$ & $\begin{array}{l}\text { In-house OHS unit } \\
2 \mathrm{OHS} \text { managers } \\
2 \mathrm{OHS} \text { professionals }\end{array}$ & 7 \\
\hline 7 & $\begin{array}{c}\text { Municipality } \\
4 \text { managers } \\
2 \text { HR professionals } \\
2 \text { safety representatives }\end{array}$ & $\begin{array}{c}\text { External OHS provider } \\
\text { | OHS manager } \\
\text { | OHS professional }\end{array}$ & 10 \\
\hline 8 & $\begin{array}{c}\text { County council } \\
2 \text { managers } \\
4 \text { HR professionals } \\
4 \text { politicians } \\
2 \text { safety representatives }\end{array}$ & $\begin{array}{l}\text { In-house OHS unit } \\
2 \mathrm{OHS} \text { managers } \\
2 \mathrm{OHS} \text { professionals }\end{array}$ & 16 \\
\hline 9 & $\begin{array}{c}\text { Municipality } \\
2 \text { managers } \\
2 \text { HR professionals } \\
3 \text { Safety representatives }\end{array}$ & $\begin{array}{c}\text { External OHS provider } \\
\text { I OHS manager }\end{array}$ & 8 \\
\hline 10 & $\begin{array}{c}\text { Municipality } \\
6 \text { managers } \\
\text { I HR professional } \\
2 \text { safety representatives }\end{array}$ & $\begin{array}{c}\text { External OHS provider } \\
\text { | OHS manager } \\
\text { । OHS professionals }\end{array}$ & 11 \\
\hline 11 & $\begin{array}{c}\text { Municipality } \\
2 \text { managers } \\
\text { I HR professional } \\
2 \text { safety representatives }\end{array}$ & $\begin{array}{c}\text { External OHS provider } \\
\text { । OHS manager } \\
3 \mathrm{OHS} \text { professionals }\end{array}$ & 9 \\
\hline Total & 70 & 30 & 100 \\
\hline
\end{tabular}


transcription agency and were read several times. Nvivo coding was used to analyze the content of the data, themalized according to a coded and categorized structure. This process included open coding, creating categories, and abstraction. During the coding stages, the researchers reflected over and discussed the coding and interpretation process in order to check quality criteria. The lists of categories were grouped under higher order headings, in order to reduce the number of categories by collapsing them into broader higher categories. Subsequently, a coding hierarchy was created using the interview guide and themes emerging from the data (Hsieh \& Shannon, 2005; Patton, 2002; Miles \& Huberman, 1994). Through interpretation, the themes were significant and important to the utilization of OHS services in the public sector and consisted of different aspects demonstrating the multitude of factors explicable for collaboration and utilization of preventive services in OHSM.

Influenced by a discourse perspective in the analyze and in order to achieve a broader understanding of the respondents' ways of talking about the phenomenon, a more detailed analysis was carried out identifying the participants' various interests and motives with respect to OHS providers. There are different approaches to critical discourse analysis; one aim of discourse theory is to focus on the specific expressions in their capacity as articulations, to analyze how they are implied in talk and other actions (Jørgensen \& Phillips, 2002). Our aim with the discourse influence was to identify how the respondents talked about their OHS provider and the discourse perspective was marked and integrated into the overall coding hierarchy. On the basis of the outcomes of the analysis, the categories and themes were presented at two workshops with respondents, public-sector OHS providers, researchers, and the reference group where the participants discussed and reflected on categories and themes and the relationships between them.

\section{Results}

In all, each organization collaborated with their OHS provider in their own unique way and, even if it should be expected, the considerable variation was surprising. At the same time, however, the pattern for utilizing services was very generic. To a great extent, services were utilized as a reaction to events, with preventive services in OHSM being the exception or, in some cases, almost nonexistent. From the organization's perspective, the OHS provider was someone to contact in the aftermath of an event. Their understanding and manner of talking about OHS providers had a traditional medical and caring focus and the perception about services and support were mainly about illness or accident, reactive and rehabilitative. In fact, only a couple of the cases indicated a high level of utilization of preventive services from the OHS provider.

Altogether, the relationship and collaboration between the public-sector organizations and their OHS providers, and ultimately the utilization of services and support, were affected by several identified factors. Three main challenges to collaboration were identified in the analysis, each of which is elaborated on below.

\section{The impact of political governance}

All five external OHS providers were contracted by municipalities. Six of the publicsector organizations had their own OHS unit, four municipalities and two county 
councils. These in-house OHS units had different forms of ownership and were organized and managed in various ways, operated as a publicly-owned corporation or as an independent department reporting directly to the central board or in a couple of cases under the direct control of the HR Department. Their situation within the organization was significant and their independence was seen as an important marker and signal, as one in-house OHS unit declared:

Of course, we feel that we are in the right place within the organization, because it would not be appropriate to be, as many others are, a part of the HR Department. We manage ourselves are not beholden to anyone. It shows that we are impartial and independent.

Another important factor for how services from the OHS provider were utilized was the financial framework. Budget sizes and limits were defined by politicians on an annual basis. The procedures for determining the size of the budget varied considerably; in many cases calculated from a cost per employee and year, in others in the form of a lump sum. Some of the cases financed a basic service provision centrally for management to use, while in others line managers had budgetary authority. This decentralization of the budget was the cause of much concern, with many managers having to weigh-up and prioritize every decision before utilizing services. The more decentralized the budget, the greater the risk that the line manager would act far too cautiously and take measures only when absolutely necessary. As one OHS respondent formulated their challenge:

It is always more difficult to argue with the people who hold the purse strings, to get them to put money upfront for something with only long-term benefits. Especially in a municipality where the budget is carried over year after year, you get nothing left for the next year.

A centrally administered budget for services and support to rehabilitation and efforts to reduce absenteeism was seen by several respondents in the public sector as a good solution. This would free individual line managers from sole responsibility for costs attributed to absenteeism due to illness and rehabilitation in their working group leaving more economical leeway for investments in preventive OHSM.

So, even if the politicians were remote from practices and activities within the organization, they provided the conditions and affected the outcome for collaboration and utilization of preventive services from their OHS provider. Only one in-house county council OHS unit deviated in their management and contact with politicians. This involved a local government committee, allowing direct and continuous updating of objectives and priorities, with politicians closely following the efforts of the OHS unit. None of the other cases had this form of close political governance and monitoring.

\section{A lack of adequate implementation and collaboration despite established OHSM structures}

Although in many of the public-sector organizations, there was an established OHSM structure, in several, there was a lack of interaction with safety committees and a limited flow of information on occupational health and safety issues. How the OHS provider becomes involved in and contributes their expert knowledge to OHSM therefore 
becomes an important factor in gaining a picture of how the utilization of preventive services and support complies with the intention of the legislation.

In all five cases with an external OHS provider, the HR Department had been responsible for the procurement process. In that process, it was largely HR alone that identified and analyzed the needs of the organization and was the point of contact with the chosen OHS provider. Safety representatives were often informed afterwards and seldom informed of the content and conditions of the contract before everything were settled. This lack of collaboration was perceived and expressed by the safety representatives in a variety of ways; some were fully satisfied with merely being informed, while others were frustrated at not being involved. It is clear that even if legislation grants safety representatives a key role in risk prevention and improving the work environment, in the context of this study some of them can be interpreted as reduced to being silent observers. They did not express any opposition, nor show any inclination to question the employer but simply silently accepted the current situation while others were more emphatic in their protests at not being involved or consulted. The benefits of working together in the procurement process and the need to maintain a dialogue regarding this in the safety committee were not entirely clear either to HR professionals or managers in general. This situation had consequences for the utilization of preventive services in OHSM and the importance of the relationship between HR and OHS provider will be discussed later in the paper.

The safety committee may be one possible avenue for the external OHS provider to obtain information or notice that something is going on. Results showed that in general, the external OHS providers had no role in OHSM and their presence on safety committees was not common practice. Being excluded from discussions where problems were identified and defined or not having an opportunity to discuss the needs of the organization, were perceived as a burden by many external OHS providers and one OHS respondent described one of the problems:

The disadvantages are that we do not know if we get to find the employees who actually have trouble and problems with illness related to their work, because they have to go to their boss first to get an order to come here and maybe it is their relationship with the boss that is a concern. (OHS provider)

The in-house OHS units were to varying degrees engaged in the safety committee, as an opportunity to draw attention to common problems in work environment or to maintain a dialogue with health and safety representatives. Even so, the use of services and support to OHSM from the OHS provider, both with regard to external providers and in-house units, was seldom discussed in the safety committees, nor analyzed or expressed in accordance with common purpose, as intended by the legislation.

So, even where there was a formal and structured arrangement for OHSM collaboration in safety committees, it did not work optimally. Another aspect was that several managers described how they had very little capacity for occupational health and safety issues due to more pressing requirements, an increased workload and constant lack of time. Instead, they reacted if something happened in their working group and subsequently adopted measures. In addition, these inabilities were reinforced by the safety representatives who made no effort to exert influence when OHSM was insufficient. 


\section{The role and impact of the HR Department}

As mentioned, one important aspect is to highlight the relationship between the HR Department and the OHS provider. In several cases, the HR Departments not only facilitated or administrated the procurement process but also defined the services and support to be supplied, in some cases being the only point of contact with the OHS provider. Indeed, this was generally an accepted and recognized state of affairs by many respondents in the organizations, with OHS providers being seen as a support to the HR Department. Significantly, this was reflected and expressed in different ways by several HR respondents, for example: 'There is a culture among us that we see the OHS provider as one of our departments, it is our extended arm'.

Respondents from the OHS providers see this situation to be problematic, as it brings with it a risk that employees and safety representatives will regard the OHS provider as a resource only for the employer, having no trust in them as an independent expert and leaving the OHS provider in difficulty regarding playing a part in OHSM. Several of the OHS providers emphasized that the relation with HR was difficult to manage. One OHS providers described the situation: 'The HR Department has settled in between, I call them gatekeepers'.

Line managers expressed that they did not really know what the OHS provider could support, apart from health examinations and rehabilitation. They did not contact the OHS provider of their own volition; they consulted their HR Department before utilizing any services. According to many HR respondents, the OHS provider was supposed to support them and not the line managers in the organization. As one HR manager declared: 'We try to steer them (the in-house OHS unit) a little in our direction, they're owned by us, so to speak'.

One explanation of the HR professionals' conceptions and attitudes toward both in-house OHS units and the external OHS providers may be that they were often instructed by management to coordinate OHSM within the organization. This assignment often included the support from the OHS provider. This kind of arrangement can be very effective and supporting toward OHSM and can have advantages, for example, to achieve greater coherence in usage of the OHS provider or to have a comprehensive approach to work environment issues and OHSM. On the other hand, it could also be a restriction on OHSM. Some HR Departments had taken over the responsibility for procurement and did not purchase preventive OHSM services. Instead, the purchase was oriented toward more individual health promoting services. Even if the understanding of workplace health promotion should be related to organizational, group, and individual efforts, the services and support deemed necessary were individual health interventions, not preventive OHSM services. The difference between health in OHSM and health in workplace health promotion was described by one HR respondent:

The safety representative's' role is to prevent; the health agent's role is to promote. The entirety of work environment legislation is based on prevention and keeping track of risks and shortcomings with a problem-oriented basis. But health agents, they are promoting, opportunity-oriented; they are resources for the manager to use in their work.

On the other hand, the OHS providers had doubts about competence of the HR Department and expressed difficulties with the fact that the employer, through their HR 
Department, did not make any deeper analysis of what kind of problems exists in the work environment. Respondents from both sides expressed the importance of working with health-related problems but at the expense of work environmental issues, as two OHS provider respondents emphasized:

[...] and when the manager calls and tells me that his staff feels so bad and ask me if I can arrange a day of pediometrics... but I said no.

They have an intention that everything should be health promoting [...] but then choose to go Nordic walking or to drive an anti-smoking campaign, when the big problems are stress and strain injuries. They forgot that.

However, despite the fact that HR Departments had an impact and to a great extent decided on the utilization of services and collaboration with OHS units and providers, they were not entirely satisfied. In several cases, dissatisfaction with delivered services and support were expressed. This sentiment of not being satisfied with the relationship was an incentive to have greater control, one HR representative declared: We may have been a little heavy-handed, but we have said that it is not for the OHS provider to go out and promote their services. That must we as employers do'.

The conditions of any relationship can be regulated in the agreement with an external OHS provider but were not characterized as easy-going in those organizations with in-house OHS units. The differences in opinion between the in-house OHS units and their respective HR Departments were more apparent, and in some cases, rivalries between HR and the OHS provider were explicitly expressed. This clearly showed that collaboration was not functioning optimally, as an HR representative with an in-house OHS unit expressed:

I can feel that our in-house OHS unit takes their own initiative and that is a little frustrating, they do things no one asked them to do. They take our fun tasks and we might be doing something and so they come in and disturb us.

The in-house OHS units were expected to subordinate themselves to the HR Department, and in these cases, the OHS provider had difficulties in operating as an autonomous part of the organization.

In addition, several HR respondents also had doubts as to what the services and support from their OHS provider were actually contributing. The services were perceived as expensive and some of the HR respondents emphasized that they could do it better themselves or had established other external contacts. One HR respondent with an in-house OHS unit expressed:

I would like to say to the OHS unit - Come on! I know a lot of them and their skills, but we (the HR Department) can do these things too, show us something of interest and just do not assume that we will purchase. We have become so aware and this is perhaps a challenge for the OHS providers; get to know your HR Department. We are more demanding today and they must work for it.

This view highlights a further complicating factor in the relationship between HR and OHS providers; competences and knowledge were considered to be too equal. This view 
was also confirmed by some responding managers who explained that they do not know the difference between services provided by the HR Department and the OHS provider; their services were too similar.

They underlined that it was very much a matter of expertise on the part of the HR Department regarding occupational health and safety and OHSM. One OHS provider claimed; 'There is an old competition. They (HR Department) do not have competence for occupational health and safety, they do not comprehend it at an overall level, and instead they work at detail level.'

Undoubtedly, HR personnel without adequate knowledge of occupational health and safety may adversely affect OHSM and especially how the preventive services and support of an OHS provider are utilized.

\section{Discussion}

Results showed that OHS providers do not support public-sector organizations as an independent resource for preventive OHSM services as intended by the legislation. The lack of preventive services was explicit. Instead, with the exception of a few isolated cases, the collaboration with the OHS provider had a strong connection to the HR Department and any support was to a large extent in the form of individual health promoting services or rehabilitation.

This is in line with the HR transformation with processes to maximize employee productivity and efficiency and to enhance employee capabilities (Ulrich, 1995). The public sector has adopted this links from HR performance in private sector, expecting similar positive effects (Pichault, 2007) and HR professionals use the HR transformation to gain greater influence in their organizations (Boglind et al., 2011). Even if HR has been primarily focused on the role as a strategic business partner, it is essential that HR offers support and advice to front-line managers (Marchington, 2015).

However, the Swedish law is clear; the need for and utilization of services and support from an OHS provider for an organization's OHSM should be a matter for discussion and collaboration between employer/front line managers and employees/safety representatives. Such involvement requires a well-developed system at the workplace (Fedotov, 2005) and a successful development of this form of collaboration is more likely with frequent contact with the OHS provider at different levels in the organization (Schmidt et al., 2015).

If $\mathrm{HR}$ is the only point of contact, this relationship will jeopardize the independent role of the OHS provider who will not be able to comply with the intentions of the relevant legislation and regulation. There is a considerable risk that such circumstances contribute to insecurity about their independence among employees with a subsequent loss of confidence in the OHS provider. From this, it follows that OHS providers, when their only point of contact is the HR Department, also have limited access to actual workplaces and to local knowledge, experiences, activities, and discussions on health and safety (Schmidt et al., 2015).

The transformation of how the working environment is managed brought about by the impact of NPM and the transformation of the role of HR has been going on in Sweden for decades and these developments have contributed to substantial changes in many processes and approaches in the public sector. Focus in NPM is on efficient use 
of public resources and less on the actual effect on the working environment. It is clear that this changing nature also has change the role of OHS providers and utilization of services. One reason according to Hasle (2014) is that it is difficult to establish causal relationship between policies and strategies and the effects on health and safety outcome (Hasle et al., 2014). The efficiency of work environmental investments is commonly measured through key figures, for example, the level of sick-leave and it is hard to measure and estimate the benefits of the preventive services from OHS providers.

The business of OHS providers has also changed; they have become market-oriented and streamlined, but the social duty of OHS providers as specified in the Work Environment Act has not changed. Even the competences and skills of an OHS provider are clearly expressed in the regulations (Swedish Work Environment Authority, 2001). OHS providers are still tasked with preventing health hazards and occupational accidents at group or organization level rather than supporting individuals after the event. These developments may also have contributed to a lack of knowledge on the part of OHS providers on how to support OHSM.

One further problem identified in the study was that OHSM is not always adequately enforced within the organizations. Several managers did not consider occupational health and safety to be a priority but instead reacted in the aftermath of events. There was a lack of any ongoing dialogue regarding health and safety issues in the workplace and management did not recognize their OHS provider as an independent resource in preventive OHSM.

At the same time, together with the other changes in the public sector, the influence of trade unions has decreased and the number of safety representatives has dropped (Kjellberg, 2010). Safety representatives reported increased efforts to exert control over them rather than to collaborate and several of them did not seem aware of their opportunity and responsibility to influence. Safety representatives usually have good knowledge of occupational health and safety issues, with a good understanding of current working conditions (Sjöström, 2013). Here can the safety committees be an opportunity to a cooperative work. There is no legal requirement for any form of representation of OHS providers on safety committees; it is up to every purchaser of OHS services to decide what is most appropriate and to define this in the contract. However, the safety committee can be an arena for ongoing dialogue and the exchange of information.

So, even if structures for OHSM in the public sector were recognized, there were deficiencies or ambiguities in the opportunities available to employees and safety representatives to participate actively in OHSM. Just simply putting in place structures for OHSM is not enough. This finding corresponds to what is reported in the literature, showing that OHSM in both municipal and county council organizations was failing. For example, where a municipality's OHSM were not effective because there was a significant deficiency in the practical implementation of the system due mainly to a general lack of knowledge of OHSM among managers and employees. On the part of county councils, on the other hand, there was a lack of overall, measurable OHSM objectives (Frick \& Johanson, 2013b). The results also show the limited role played by safety representatives in these organizations, and the results of Frick (2013c) confirm this line of reasoning.

Implementation and execution are necessary and the fact that well-established practices and routines in OHSM can be advantageous to a successful collaboration with an OHS provider has been identified in a study of OHS providers in the private sector 
(Schmidt et al., 2015). Even if the employer is free to organize and delegate the organization's OHSM, legislation is clear; where necessary, there is an obligation to use an independent OHS provider or other external resource (Swedish Work Environment Authority, 2001).

As the coordinating function for the organization, HR has the ability in several ways to facilitate and support the process of OHSM with regard to managers and health and safety representatives. HR has different stakeholders; top-manager, frontline managers, safety representatives, and employees with different priorities and expectations of what HR has to fulfil and add different value to HRs contribution (De Winne et al., 2013). According to Ulrich and Dulebohn (2015), HR in the future can connect to a broader business context, to meet needs of external stakeholders. Within the HR department itself, levels of HR expertise, business knowledge, and understanding can develop in different ways and the HR role will vary both across organizations and time (Truss et al., 2002). At a local level, HR professionals can improve collaboration and strengthen interprofessional trust by encouraging interactions concerning services and support from the OHS provider and by granting legitimacy to the relationship. HR can also enhance employee engagement and trust in management by develops communications and consultations with employees and safety representatives. As Gilbreath and Montesino (2006) point out, the HR profession can be further developed and advanced in the future and suggest the HR role should be expanding, in order to improving employee well-being and organizational performance. Even if it has to be taken in account that the HR Department has no mandate to change conditions or circumstances in the work environment if necessary as that responsibility lies with line managers.

However, not all HR professionals have that kind of remit or the knowledge of work environment issues. Instead, their responsibilities are mainly focused on employees, for example, with regard to absenteeism due to illness and rehabilitation. HR management practices are used to acquire and develop an organization's capital and are associated with higher levels of productivity or effectiveness at the organizational level of analysis (Neal, 2005). Therefore, when HR defines, procures, and utilizes services from the OHS provider, there is a risk that the focus is on promoting the health of individuals. Even if this is not the intention, it is obvious that work place health promotion seems to be a separate health approach, that is, separate and not integrated with OHSM within the organization (Allender et al., 2006; Pescud et al., 2015; Leitão \& Greiner, 2017). Instead of being a complement to OHSM, this workplace health promotion has broadly taken over the orientation of OHS providers. Too little attention is paid to the formation and design of the workplace and the work itself; on organizational, social, and technical improvements in a preventive approach to developing employees. Instead, there have been substantial efforts to bolster individual health in order to cope with the work environment. Overall, there appears to be a disconnect between what OHS providers should be doing according to legislation and regulation, and what they are actually being utilized for. When all of these factors are added together, they spell out a difficult reality for the public sector. Consequently, the public sector ought to be concerned by the challenges facing it and realize the importance of taking steps to ensure the optimal health of its workforce. One step could be to better follow-up OHSM within the organizations and, where necessary, seek additional resources in support of preventive OHSM from their OHS provider.

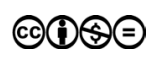




\section{Conclusion}

The contribution made by OHS providers in terms of services delivered and support for preventive OHSM in the Swedish public sector is limited. Instead, to a large extent to the HR department impact, mostly individual health-related services are utilized. Our analysis reveals that, due to several factors, the intentions of the legislation regarding collaboration with and the utilization of services from OHS providers are not complied with. The current form of utilizing services from OHS providers will not contribute to an improvement in the work environment or support OHSM in the public sector.

\section{Acknowledgment}

The study was financially supported by AFA Insurance, Doc. No. 110206 and Forte, Swedish Research Council for Health, Working Life and Welfare, Doc. No. 2010-1563, Sweden.

\section{References}

Allender, S., Colquhoun, D., Kelly, P. (2006). Competing discourses of workplace health. Health: An interdisciplinary Journal for the Social Study of Health, Illness and Medicine. Vol. 10(1): pp. 75-93, London: SAGE Publications. doi: https://doi. org/10.1177/1363459306058989

Arbejdstilsynet (2013). Evaluering af samarbejdet om arbejdsmiljø $i$ virksombeder. [Evaluation of collaboration on working environment in companies] (AMO) Oxford Research A/S; Kubix ApS; Center for Arbejdslivsforskning, ENSPAC, Roskilde Universitet. Available at: doi: https://arbejdstilsynet.dk/da/om\%20arbejdstilsynet/strategier-evalueringer-og-rapporter/evaluering-af-amo

Boglind, A., Hällstén, F., Thilander, P. (2011). HR transformation and shared services: Adoption and adaptation in Swedish organisations. Personnel Review, Vol. 40, Iss. 5, pp. 570-588. doi: http://doi.org/10.1108/00483481111154441

Brown, K. (2004). Human resource management in the public sector. Public Management Review. 6(3) pp. 303-9. doi: https://doi.org/10.1080/1471903042000256501

Danish Government (2011). Agreement between the Danish government (Denmark's Liberal Party and the Conservative People's Party), the Social Democratic Party, the Danish People's Party and the Social Liberal Party. A strategy for working environment efforts up to 2020. doi: http://engelsk.arbejdstilsynet.dk/en/ (3 April, 2017).

Dellve, L., Skagert, K., Eklöf, M. (2004). Delaktighet och struktur $i$ systematiskt arbetsmiljöarbete. Betydelsen för rapporterade arbetsskador och arbetshälsa bland personal $i$ kommunal vaird och omsorg. [Participation and structure of systematic work. The significance of reported occupational injuries and health among staff in Community Care] Rapport 2004:107. Göteborg: Arbets- och miljömedicin.

Dellve, L., Skagert, K., Eklöf, M. (2008). The impact of systematic health \& safety management for occupational disorders and work ability. Soc Sci \& Med, 67(6), pp. 965-70. doi: https://doi.org/10.1016/j.socscimed.2008.05.030

De Winne, S., Delmotte, J., Gilbert, C., Sels, L. (2013). Comparing and explaining HR department effectiveness assessments: evidence from line managers and trade union repre- 
sentatives. The International Journal of Human Resource Management, Vol. 24, No. 8, pp. 1708-1735. doi: http://doi.org/10.1080/09585192.2012.725069

Diefenbach, T. (2009). New public management in public sector organizations: The dark sides of managerialistic 'enlightenment'. Public Administration, Vol. 87, No. 4, pp. 892-909. doi: https://doi.org/10.1111/j.1467-9299.2009.01766.x

Fedotov, I. (2005). Occupational Health Services as a Key Element of National Occupational Safety and Health Systems. SJWEH Supplements, pp. 16-18.

Frick, K. (2011). Worker influence on voluntary OHS management systems - A review of its ends and means. Safety Science, 49, pp. 974-987. doi: http://doi:10.1016/j.ssci.2011.04.007

Frick, K. (2013a). Work Environment Dialogue in a Swedish Municipality — Strengths and Limits of the Nordic Work Environment Model. Nordic journal of working life studies 3, 1. doi: https://doi.org/10.19154/njwls.v3i1.2521

Frick, K., Johanson U. (2013b). Kunskapssammanställning Systematiskt arbetsmiljöarbetesyfte och inriktning, hinder och möjligheter i verksambetsstyrningen. En analys av svenska fallstudier. [State of knowledge report on Systematic Work Environment Management - purpose and direction, obstacles and opportunities in organization management. An analysis of Swedish case studies]. Report 2013:11. Stockholm: Swedish Work Environment Authority.

Frick, K. (2013c). Kunskapssammanställning Systematiskt arbetsmiliöarbete- syfte och inriktning, hinder och möjligheter i verksambetsstyrningen. Del II: Hur SAM genomförs $i$ branscherna. [State of knowledge report on Systematic Work Environment Management purpose and direction, obstacles and opportunities in organization management Part II: How SWEM is implemented in industries]. Report 2013:12. Stockholm: Swedish Work Environment Authority.

Frick, K. (2014). The 50/50 Implementation of Sweden's Mandatory Systematic Work Environment Management, Policy and Practice in Health and Safety, 12:2, pp. 23-46, doi: http://doi.10.1080/14774003.2014.11667802

Gilbreath, B., Montesino, M. U. (2006). Expanding the HRD Role: Improving Employee Well-Being and Organizational Performance. Human Resource Development International. Vol. 9. No. 4, pp. 563-571. doi: https://doi.org/10.1080/13678860601032684

Gunnarsson, K., Andersson, I.-M., \& Josephson, M. (2011). Swedish entrepreneurs' use of occupational health services. Workplace Health \& Safety, 59, pp. 437-445.

Hall, P. (2013). NPM in Sweden: The Risky Balance between Bureaucracy and Politics.In , Sandberg, A. (ed.)Nordic Lights Work, Management and Welfare in Scandinavia. SNS Förlag, Falun. 406-419. ISBN: 978-91-86949-37-2. doi: https://doi.org/10.7202/1024218ar

Hasle, P., Limborg H. J., \& Nielsen K. T. (2014). Working environment interventions - Bridging the gap between policy instruments and practice. Safety Science, 68, pp. 73-80. doi: http://dx.doi.org/10.1016/j.ssci.2014.02.014

Hasselbladh, H., Bejerot, E., \& Gustafsson, R. Å. (2008). Bortom new public management institutionell transformation i svensk sjukvard [Beyond New Public Management Institutional Transformation in the Swedish Health Care]. Lund: Academia Adacta.

Hsieh, H. F., Shannon, S. E. (2005). Three approaches to qualitative content analysis. Qual Health Res. 15(9) pp. 1277-1288. doi: https://doi.org/10.1177/1049732305276687

Hämäläinen, R.-M., Husman, K., Räsänen, K., Westerholm, P., \& Rantanen, J. (2001). Survey of the Quality and Effectiveness of Occupational Health Services in the European Union and Norway and Switzerland. People and Work - Research Reports 45. Helsinki: Finnish Institute of Occupational Health.

Ibsen, C. L., Larsen, T. P., Madsen, J. S., Due, J. (2011). Challenging Scandinavian employment relations: the effects of new public management reforms. The International Journal of Human Resource Management, Vol. 22, No. 11, pp. 2295-2310. doi: https://doi.org/1 $\underline{0.1080 / 09585192.2011 .584392}$ 
Jørgensen, M., Phillips L. J. (Eds.) (2002). Discourse Analysis as Theory and Method. London: SAGE Publications Ltd. doi: http://dx.doi.org.ezp.sub.su.se/10.4135/9781849208871

Kankaanpää, E., Suhonen, A., Valtonen, H. (2008). Promoting prevention with economic arguments - The case of Finnish occupational health services. BMC Public Health, 8:130. doi: http://doi/10.1186/1471-2458-8-130

Kankaanpää, E., Linnosmaa, I., Valtonen, H. (2013). Market competition, ownership, payment systems and the performance of health care providers - a panel study among Finnish occupational health services providers. Health Economics, Policy and Law, 8, pp. 477-510. doi: http://doi:10.1017/S174413311200031X

Kamp, A., Klemsdal, L., Gonäs, L. (2013a). Working in the Public Sector Introduction to the Thematic Issue, Nordic journal of working life studies. Vol. 3. No. 2. pp. 1-8. doi: https:// doi.org/10.19154/njwls.v3i2.2547

Kamp, A., Hohnen, P., Hvid, H., Scheller, V. K. (2013b). New Public Management - Konsekvenser for arbejdsmiliø og produktivitet. [New Public Management - The consequences for the work environment and productivity]. Paper for Centre for Working Life Research, No.3. Roskilde University, Roskilde, Denmark. ISSN 224-702X.

Kjellberg, A. (2010). Kollektivavtalens täckningsgrad samt organisationsgraden hos arbetsgivarförbund och fackförbund. [The scope of collective bargaining and level of organization among industry organizations and trade unions]. Lund: Lund University, Sociology Department.

Leitão, S., Greiner, B. A. (2017). Psychosocial, Health Promotion and Safety Culture Management - Are Health and Safety Practitioners involved? Safety Sciences, 91, pp. 84-92. doi: https://doi.org/10.1016/j.ssci.2016.07.002

Lie, A., Bjørnstad, O. (2015). Accreditation of occupational health services in Norway. Occup Med. 65(9): 722-724. doi: https://doi.org/10.1093/occmed/kqv120

Lund, T., Christensen, K. B., Vaez, M., Labriola, M., Josephson, M., Villadsen, E., et al. (2008). Differences in sickness absence in Sweden and Denmark: the cross national HAKNAK study. Eur J Public Health 19(3), 343-349. doi: https://doi.org/10.1093/ eurpub/ckn128

Marchington, M. (2015). Human resource management (HRM): To bust looking up to see where it is going longer term? Human Resource Management Review, 25, pp. 176-187. doi: http://doi.org/10.1016/j.hrmr.2015.01.007

Miles, M. B., Huberman, A. M. (1994). Qualitative data analysis: An expanded sourcebook., California: Thousand Oaks, Sage Publications.

Målqvist, I., Åborg, C., Forsman, M. (2011). Styrformer och arbetsförhållanden inom vård och omsorg - en kunskapssammanställning om New Public Management. [Governance and working conditions in healthcare - a summary of knowledge on New Public Management]. Karolinska Institutet Department of Public Health, 2011:11. Stockholm: Karolinska Institutet.

Neal, A., West, M. A., Patterson, M. G. (2005). Do orgnizational Climant and Competitive Strategy Moderate the Relationship Between Human Resource Management and Productivity? Journal of Management, 31(4), pp. 492-512. doi: https://doi. org $/ 10.1177 / 0149206304272188$

Ollé-Espluga, L., Vergara-Duarte, M., Francesc Belvis, F., Menéndez-Fuster, M., Jódar, P., Benach, J. (2015). What is the impact on occupational health and safety when workers know they have safety representatives? Safety Science, 74, pp. 55-58. doi: https://doi. org/10.1016/j.ssci.2014.11.022

Official Reports of the Government of Sweden (2004). Utveckling av god företagshälsovård. Ny lagstiftning och andra åtgärder. SOU 2004:113. [Developing good occupational health; New legislation and other measures]. Betänkande av 2003 års företagshälsovårdsutredning. 
Official Reports of the Government of Sweden (2007). Ny företagshälsovård - ny kunskapsförsörjning. SOU 2007:91. [New occupational healthcare - new provision of knowledge]. Betänkande av Utredningen Framtidens FHV-utbildning.

Official Reports of the Government of Sweden (2011). Kunskapsområdet företagshälsovård. En rapport om utbildning, utveckling och forskning. SOU 2011:79. [Knowledge area occupational health services, A report on education, development and research]. Slutrapport från FHV-delegationen.

Patton, M. Q. (2002). Qualitative research \& evaluation methods. London: Sage Publications.

Paulsson, G. (2012). The Role of Management Accountants in New Public Management. Financial Accountability \& Management, 28(4), 378-394. doi: https://doi.org/10.1111/ j.1468-0408.2012.00552.x

Pescud, M., Teal, R., Shilton, T., Slevin, T., Ledger, M., Waterworth, P., Rosenberg, M. (2015). Employers' views on the promotion of workplace health and wellbeing: a qualitative study. BMC Public Health. doi: https://doi.org/10.1186/s12889-015-2029-2

Pichault, F. (2007). HRM-based reforms in public organisations: problems and perspectives. Human Resource Management Journal, Vol. 17, No. 3, pp. 265-282.

Schmidt, L., Sjöström, J. Antonsson, A-B. (2015). Successful collaboration between occupational health service providers and client companies: key factors. Work (51) pp. 229-237. doi: https://doi.org/10.3233/WOR-141855

Selberg, R. (2013). Nursing in times of neoliberal change: An Ethnographic

Study of Nurses' Experiences of Work Intensification. Nordic journal of working life studies, Vol. 3, No. 2, pp. 9-35.

Sjöström, J. (2013). Det komplexa deltagandet - Praktikgemenskaper, kunskapsprocesser och arbetsmiliöarbete vid ett pappersbruk. [The complex participation. Practice communities, knowledge processes and work environment work at a paper mill]. Tema teknik och social förändring. Linköping: Linköpings Universitet. (Ph.D.thesis).

Sjöström, J., Frick, K. (2017). Worker participation in the management of occupational safety and health - qualitative evidence from ESENER -2. Country report Sweden. European Agency for Safety and Health at Work (EU-OSHA).

Sveriges Företagshälsor (2016). Trade information. doi: http://www.foretagshalsor.se/branschinfo/branschfakta (22 October, 2016).

Sverke, M., Falkenberg, H., Kecklund, G., Magnusson Hanson, L., Lindfors P. (2016). Kunskapssammanställning Kvinnors och mäns arbetsvillkor - betydelsen av organisatoriska faktorer och psykosocial arbetsmiliö för arbets- och hälsorelaterade utfall. [State of knowledge report on women and men's working conditions - the importance of organizational factors and psychosocial work environment for work and health related outcomes]. Report 2016:2, Stockholm: Swedish Work Environment Authority.

Swedish Agency for Public Management (2001). Utnyttja företagshälsovården bättre. [Better utilization of occupational health services]. Report 2001:29.

Swedish Agency for Public Management (2015). Den offentliga sektorn i korthet. [The public sector in brief]. Report 2015/6-5.

Swedish Work Environment Authority (2001). Systematiskt Arbetsmiljöarbete [Systematic work environment work]. AFS 2001:01. doi: https://www.av.se/globalassets/filer/publikationer/foreskrifter/systematiskt-arbetsmiljoarbete-foreskrifter-afs2001-1.pdf (22 October, 2016)

Swedish Work Environment Authority (2014a). Work Environment Act, s. 3, $\mathbb{S} 1$ a; s. 6, \$1. doi: https://www.av.se/arbetsmiljoarbete-och-inspektioner/lagar-och-regler-om-arbetsmiljo/arbetsmiljolagen/\#1 (3 April, 2017)

Swedish Work Environment Authority (2014b). Work Environment Act, s. 3, $\mathbb{2 a} \&$ c. doi: https://www.av.se/arbetsmiljoarbete-och-inspektioner/lagar-och-regler-om-arbetsmiljo/ arbetsmiljolagen/\#1 (22 October, 2016) 
Swedish Work Environment Authority (2014c). Work Environment Act, s. 6, $\mathbb{S}$ 2. doi: https://www.av.se/en/work-environment-work-and-inspections/acts-and-regulations-about-work-environment/the-work-environment-act/ (19 November, 2016)

Truss, C., Gratton, L., Hope-Hailey, V., Stiles, P., Zaleska, J. (2002). Paying the piper: choice and constraint in changing HR functional roles. Human Resource Management Journal, Vol. 12. No. 2, pp. 39-63.

Truss, C. (2008). Continuity and change: The role of the HR function in the modern public sector. Public Administration, 86(4):1071-1088. doi: https://doi.org/10.1111/j.14679299.2008.00718.x

Ulrich, D., Dulebohn, J. H. (2015). Are we there yet? What's next for HR? Human Resource Management Review, 25, pp. 188-204. doi: http://dx.doi.org/10.1016/j. hrmr.2015.01.004

Vinberg, S., Romild, U., Landstada, B. J. (2015). Prevention and rehabilitation in Swedish public sector workplaces: Effects on co-workers' and leaders' health and psychosocial working conditions Work 52, pp. 891-900. doi: http://doi.org/10.3233/WOR-152132

Vinberg, S., Torsdatter Markussen, L., Landstad, B. J. (2017). Cooperation between Occupational Health Services and Small-Scale Enterprises in Norway and Sweden. Workplace Health \& Safety, doi: https://doi-org.ezp.sub.su.se/10.1177/2165079916668527

Vingård, E., Lindberg, P., Josephson, M., Voss, M., Heijbel, B., Alfredson, L. et al. (2005). Long term sick listing among women in the public sector and its associations with age, social situation, lifestyle and work factors: A three-year follow-up study. Scandinavian Journal of Public Health, 33(5), pp. 370-375. doi: https://doi.org/10.1080/14034940510005860

Walters, D., Nichols, T. (2007). Worker representation and workplace health and safety. Basingstoke; Palgrave Macmillan. doi: https://doi.org/10.1057/9780230210714

Westerholm, P., Bostedt, G. (2004). Kan företagshälsovården lösa sjukskrivningskrisen. I Hogstedt C, Bjurvald M, Marklund S, Palmér E, Theorell T. (red.) Den höga sjukfrånvaron: sanning och konsekvens. [Can occupational health services solve the sick-leave crisis. The high level of absenteeism due to sickness; truth or consequence]. Swedish National Institute of Public Health, Sandviken.

Westerholm, P., Hasle, P., Fortuin, R. (2000). Multidisciplinary health services as external agents of change. In Frick, K., Langaa Jensen, P., Quinlan, M. Wilthagen, T. (red.): Systematic Occupational Health \& Safety Management. Perspectives on International Development. Oxford: Pergamon Press. pp. 311-328.

Yin, R. (1994). Case study research. California: Thousand Oaks, Sage Publication. 